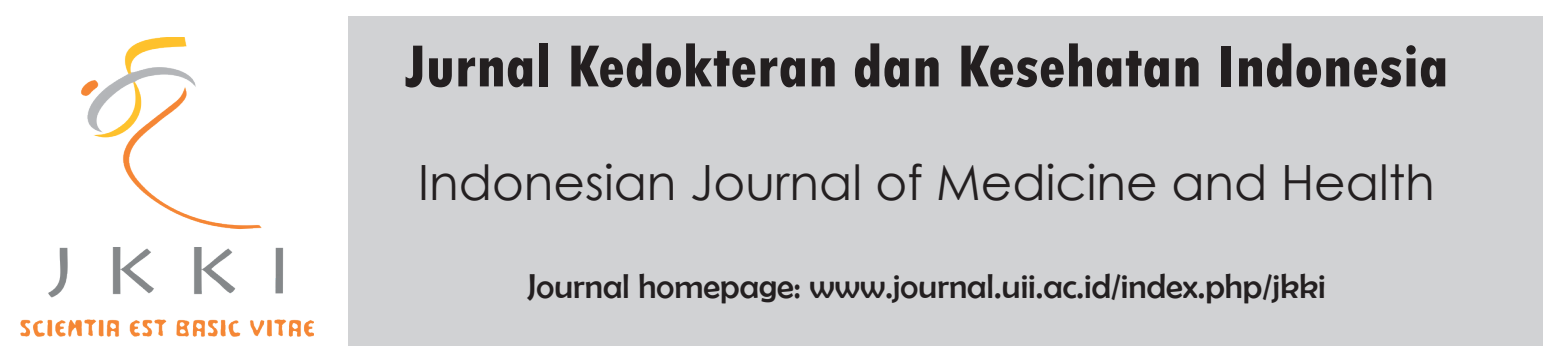

\title{
Effect of giving ethanol multistep doses to level of SGPT and SGOT in wistar rats (Rattus norvegicus)
}

\author{
Istiqomah Kurniawati $^{1,}$ Titis Nurmasitoh ${ }^{* 2}$, Taufik Nur Yahya ${ }^{3}$ \\ ${ }^{1}$ Student of Faculty of Medicine, Islamic University of Indonesia \\ ${ }^{2}$ Department of Physiology, Faculty of Medicine, Islamic University of Indonesia \\ ${ }^{3}$ Faculty of Medicine, Islamic University of Indonesia
}

Original Article

\begin{tabular}{|c|c|}
\hline & ABSTRACT \\
\hline ARTICLE INFO & Background: Ethanol is one types of alcohol used in beverages. Excessive \\
\hline $\begin{array}{l}\text { Keyword: } \\
\text { Ethanol, } \\
\text { SGOT } \\
\text { SGPT }\end{array}$ & $\begin{array}{l}\text { use of ethanol causes damage to organs, especially in the liver. Liver, which } \\
\text { is an organ in the body, serves as the metabolism of various substances in- } \\
\text { cluding ethanol. Liver damage that occurs can be known with one of these } \\
\text { liver function examination, which check the levels of SGPT and SGOT. } \\
\text { Objective: This research aims to look for the difference of SGPT's and } \\
\text { SGOT's levels between ethanol multistep doses group and control group } \\
\text { in Wistar rats (Rattus norvegicus) SGPT and SGOT levels. }\end{array}$ \\
\hline $\begin{array}{l}\text { *Corresponding author: } \\
\text { titisnurmasitoh@gmail.com }\end{array}$ & $\begin{array}{l}\text { Methods: This study used an experimental research design with post test } \\
\text { only control group design. The sample consisted of } 21 \text { male Wistar rats, } \\
\text { which were divided into } 3 \text { groups. Each group consisted of } 7 \text { rats. The first } \\
\text { group (K1) was the control group, which was given aquades. The sec- } \\
\text { ond group (K2) were given ethanol } 20 \% \text { as } 2 \mathrm{~g} / \mathrm{kg} \text { pe roral. And the third } \\
\text { group (K3) were given with } 25 \% \text { ethanol as } 2.5 \mathrm{~g} / \mathrm{kg} \text { peroral. The treat- } \\
\text { ment was given for } 4 \text { weeks. At the } 31 \text { st day blood was taken from orbitalis } \\
\text { sinus as much as } 1 \text { ml for check the level of SGPT and SGOT. } \\
\text { Results: The results are the average increase of SGPT and SGOT levels in } \\
\text { K2 compared to the K1. While on K3 showed that the average levels of } \\
\text { SGPT and SGOT were lower than K1. SGPT levels showed a significant dif- } \\
\text { ference (p<0.05) in all treatment groups in comparison with the control } \\
\text { group. The value of SGOT did not show a significant difference (p>0.05 ). } \\
\text { Conclusion: There is significant differences in the levels of SGPT treat- } \\
\text { ment group in comparison with the control group, but there is no signifi- } \\
\text { cant differences in the level of SGOT. }\end{array}$ \\
\hline
\end{tabular}

Latar Belakang: Etanol merupakan sebutan untuk alkohol yang digunakan dalam minuman. Penggunaan etanol yang berlebihan akan menyebabkan kerusakan pada organ tubuh, terutama hepar. Hepar berfungsi sebagai tempat metabolisme berbagai zat termasuk etanol. Kerusakan hepar yang terjadi dapat diketahui salah satunya dengan pemeriksaan fungsi hepar, dengan memeriksa kadar SGPT dan SGOT.

Tujuan: Penelitian ini bertujuan untuk melihat apakah terdapat perbedaan kadar SGPT dan SGOT antar kelompok yang diberi etanol dosis bertingkat dibandingkan dengan kontrol pada tikus galur Wistar (Rattus norvegicus).

Metode: Penelitian ini menggunakan desain penelitian eksperimental dengan posttest only with control 
group design. Penelitian dilakukan menggunakan tikus galur Wistar jantan berjumlah 21 ekor, yang dibagi menjadi 3 kelompok. Setiap kelompok terdiri atas 7 ekor tikus. Kelompok pertama (K1) merupakan kelompok kontrol yang diberi aquades. Kelompok kedua (K2) diberi etanol 20\% sebanyak 2gr/ kgBB. Kelompok 3 (K3) diberi etanol 25\% sebanyak 2,5gr/kgBB. Perlakuan dilakukan selama 4 minggu. Pada hari ke-31 dilakukan pengambilan darah pada sinus orbitalis subjek sebanyak $1 \mathrm{ml}$ untuk dilakukan pemeriksaan SGPT dan SGOT.

Hasil: Pada penelitian ini didapatkan hasil adanya rata-rata kenaikan kadar SGPT dan SGOT pada K2 dibandingkan dengan K1. Sedangkan pada K3 menunjukkan kadar SGPT dan SGOT yang lebih rendah dibandingkan dengan K1. Kadar SGPT ini menunjukkan perbedaan yang signifikan $(p<0,05)$ pada semua kelompok perlakuan dibanding dengan kelompok kontrol. Sedangkan untuk kadar SGOT didapatkan perbedaan yang tidak bermakna ( $p>0,05)$.

Kesimpulan: Terdapat perbedaan signifikan kadar SGPT kelompok perlakuan dibandingkan dengan kelompok kontrol, namun tidak terdapat perbedaan yang signifikan kadar SGOT

\section{INTRODUCTION}

The liver is one of the organs that is responsible for the metabolism of various substances. Metabolism in liver cells is a series of important biochemical reactions in the body, in which each cell provides substrate and energy from one system to another. Synthesis and processing of various substances that enter the body are also made by the liver as the metabolism of carbohydrates, fats, and proteins. Of the metabolic processes, the liver cells are able to produce some substances like glucose is formed from gluconeogenesis, to form lipoproteins for the transport of fats, the formation of plasma proteins, and many other results. The function of various reactions is to sustain the survival of any organism. ${ }^{1}$ In addition to macromolecular substances, the liver also metabolizes other substances that enter the body such as drugs and alcohol. The metabolism of both ingredients, especially alcohol produces substances that are toxic to the liver. The entered alcohol into the body cannot be stored and must be oxidized primarily in the liver. This oxidation process gives an injury to the liver. ${ }^{2}$

Alcohol is a group of compounds contain- ing one or more hydroxy groups or $\mathrm{OH}$. Alcohol is one of the chemicals that can be converted into various types of other compounds. Alcohol, which is available on the market and consumed as a beverage, is one type of ethanol with chemical formula $\mathrm{CH} 3 \mathrm{CH} 2 \mathrm{OH}$. Overloaded Ethanol can damage the liver due to metabolic processes as it produces toxic substances and causes injury to the liver. ${ }^{3}$

Currently, alcoholic beverages has become a common beverage, which is consumed widely by various groups. The increasing number of types, brands, and the outstanding amount of alcoholic beverages enhance the availability of alcohol to people. Alcohol has the effect of medications such as sedatives i.e when it is consumed in small amounts, pose relax and reduce anxiety effects of the drinker. Because of this nature, potentially leading to alcohol dependence favors the abuse of alcohol significantly. World Health Organization (WHO) classifies alcohol into the class of narcotics, psychotropic and addictive substances (drugs). ${ }^{4}$ Today, the incidence of alcohol abuse in the world has reached 38.3\%, with an average age of 15 years and above. ${ }^{5}$ Approximately 25\% of all alcohol users have problems due to these habits, both in terms of social life, and work, as well as health. ${ }^{6}$ In Indonesia, the consumption of alcoholic beverages is increasing every year. Currently there are 3.4 million people addicted to alcohol, among them $80 \%$ are $20-24$ years aged. ${ }^{7}$

As a result of excessive alcohol use, the occurrence of metabolism and detoxification in the body has been increased. Continuous significant amount of Metabolism and detoxification can cause damage to the liver. In this process, the hepatocytes cells can be damaged. One of the privileges of liver cells is the ability to regenerate itself when it is damaged. However, in case of the excessive consumption of alcohol and the increasing number of damaged cells, the ability to regenerate cells decreases. It can cause extensive damage to the liver and disrupt its function. ${ }^{3}$

Damage that occurs in the liver can be detected by physical examination and investigation. From the physical examination can be found a variety of manifestations, one of which is jaundice. Investigations are used to detect damage to the liver is a liver function test. One of the appeared results is the increase in 
serum enzymes such as SGPT and SGOT. The test for the measurement of serum enzymes becomes sensitive and specific so that test is most often performed to indicate liver damage. ${ }^{8}$ This study aims to determine whether there is differences in SGPT and SGOT levels after administration of graded doses of ethanol in Wistar rats (Rattus norvegicus).

\section{METHODS}

This research is an experimental research laboratory with designing the post-test- of control group only. The study was conducted at the Integrated Research and Testing Laboratory (LPPT) Gadjah Mada University, Yogyakarta for approximately 6 weeks. To get the ethical clearance, this study was submitted to Research Committee of Ethics at the Medical Faculty of Medicine and Health, Islamic University of Indonesia with protocol number 38/Ka.Kom.Et/70/KE/III/2015.

Twinty one males Wistar rats (Rattus novergicus) having aged 1-2 months and weight about 100 grams were used for experimental samples. Samples were collected from Integrated Research and Testing Laboratory (LPPT) of the Gajah Mada University. The number of samples used was determined by following the magnitude of Festing formula, namely:

$\mathrm{E}=\mathrm{N}-\mathrm{T}$.

E: Assessment with value of 10-20.

$\mathrm{N}$ : the number of animals per group

$\mathrm{T}$ : number of treatment groups.

In this study, 21 animals were used tail with 3 treatment groups. So we get: $\mathrm{E}=(7 \mathrm{x} 3)-3=18.21$ subjects were divided into three groups with each group consisting of 7 animals. The division of groups of rats were categorized as follows:The control group (K1): distilled water was given orally for 30 days. The treatment group 1 (K2): ethanol was given orally at a dose of $2 \mathrm{~g} / \mathrm{kg}$ per day for 30 days. The treatment group 2 (K3): ethanol was given orally at a dose of $2.5 \mathrm{~g} / \mathrm{kg}$ per day for 30 days.

After treatment for 30 days, on day 31, blood samples were taken via the orbital sinus. The blood was then centrifuged for taking serum as a sample inspection of SGPT and SGOT. The level of SGPT and SGOT was mea- sured by spectrophotometer.

\section{RESULTS}

Wistar rats (Rattus norvegicus) were treated according the group for 30 days. On the 31st day, venous blood samples were taken to examine levels of SGPT and SGOT enzymes. Blood samples were taken via the orbital sinus of rat. Before taking blood, the rats were given injections of ketamine for the purpose of anesthesia and relax. Then the blood samples were centrifuged to obtain serum. Subsequently, the levels of SGOT and SGPT in the serum was tested with spectrophotometric method. The results of the level of SGPT and SGOT after treatment are listed in Table 1.

Table 1 shows the average SGPT and SGOT each group. The control group is considered to have ALT and AST levels were normal. The increase in SGPT and SGOT levels seen from a comparison of each treatment group and control group.

Table 1 The average levels of SGPT and SGOT in rat after treatment

\begin{tabular}{lll}
$\begin{array}{l}\text { Treatment } \\
\text { group }\end{array}$ & $\begin{array}{l}\text { Average SGPT } \\
\text { level (u/L) } \pm \text { SD } \\
\text { (Post test) }\end{array}$ & $\begin{array}{l}\text { Average SGOT } \\
\text { level (u/L) } \pm \text { SD } \\
\text { (Post test) }\end{array}$ \\
\hline K1 & $55.85 \pm 5.28$ & $111.47 \pm 7.40$ \\
K2 & $67.00 \pm 7.37$ & $122.03 \pm 14.99$ \\
K3 & $42.40 \pm 6.75$ & $109.19 \pm 12.89$ \\
One way & $0,000^{*}$ & $0.138^{*}$ \\
ANOVA & & \\
Test & & \\
\hline
\end{tabular}

* One Way ANOVA test (post-test) significant if: $\mathrm{p}<0,05$ Description:

K1: Control group

K2 : Treatment group

K3: Treatment group at different doses..

Based on Table 1, it can be seen that the highest average level of SGPT and SGOT was found in $\mathrm{K} 2$, which is the group with the administration of $20 \%$ ethanol as much as $2 \mathrm{~g} /$ kg orally. Compared to the control group, there are differences in both treatment groups. On average K2 showed a rise of SGPT and SGOT in comparison with the control group (K1). While the average K3 showed a lower percentage both for SGPT and SGOT compared to the control group. 
SGPT and SGOT levels were tested statistically using one way ANOVA test with 95\% level of confidence after finding normal data distribution and variance. Oneway ANOVA test showed a significant difference $(p<0.05)$ for the average SGPT, with $p=0.000$ (Table 1). Then Posthoc Tukey HSD was analyzed to determine the average difference between each group. Posthoc test results showed significant differences of SGPT levels between groups K1 and $\mathrm{K} 2$ with $\mathrm{p}=0.013$. It means that there is an increase in SGPT levels in the group of rats by administration of ethanol $20 \%$ as much as $2 \mathrm{~g} / \mathrm{kg}$ body weight than the control group. Posthoc analysis results in group K1 and K3 showed a significant difference with $\mathrm{p}=0.003$. It indicates that there are significant differences in the levels of SGPT in the K3 group compared to the control group. Posthoc test results on K2 and K3 group also showed a significant difference indicated with $p=0.000$. It indicates that there is significant differences of the SGPT levels at different doses of ethanol. So the group K1, K2, and K3 showed significant differences in levels of SGPT levels respectively.

To test SGOT with oneway ANOVA showed a non-significant $(\mathrm{p}=0.138)$. It is seen from the Table 1 that there is an increase of SGOT value at K2 compared to K1. While K3 showed a decrease in the average levels of SGOT in comparison with the control group (K1).

\section{DISCUSSION}

Ethanol or ethyl alcohol is the type of alcohol that is widely used, both in the pharmaceutical industry, cosmetics, as well as alcoholic beverages. Today the use of alcohol in the beverage industry is increasing. Ethanol is a substance that can induce hepatotoxic liver damage. ${ }^{9}$ Excessive use of ethanol or in a long period of time can cause damage to the liver, because most of the ethanol metabolism occurs in the liver. ${ }^{10}$ Damage that occurs in the liver can be detected through examination of liver function. SGPT and SGOT including one liver enzyme used for liver function tests.8

SGPT (serum glutamic pyruvic transaminase) or ALT (alanine aminotransferase) is an enzyme that just available in the liver. On a mild disorder of the liver cells, the cytoplasmic enzyme, especially enzymes ALT seeps into the serum. Therefore, SGPT enzyme lev- els is unique and specific to the liver cell damage. Thus, SGPT can be used as a good indicator to see liver damage even in a mild degree. In humans, the normal value SGPT enzyme levels is ranging from 0 to $35 \mathrm{u} / \mathrm{L}^{11}$

SGOT (serum glutamic oxaloacetic transaminase) or also called AST (aspartate aminotransferase) is an enzyme that catalyzes the reversible transfer of an amino group of aspartate and $\alpha$-ketoglutarate to form glutamate and oxaloacetate. This reaction is important for maintaining homeostasis in the organism. This enzyme is normally located in the liver and other organs. Parts of the body that have SGOT are the liver, heart cells, brain, red blood cells, and muscle cells. Therefore, owned by organs other than the liver, AST is not specific indicate damage to the liver. The normal levels of SGOT in the blood is in the range $6-34 \mathrm{U} / \mathrm{L}$ in men and $8-40 \mathrm{U} / \mathrm{L}$ in women. ${ }^{12}$

In this study conducted by administering ethanol treatment in the 2 groups with different doses and compared with the control group. In the control group (K1) SGPT and SGOT levels are considered a normal rate. $20 \%$ ethanol was given on Group 2 (K2) at a dose of $2 \mathrm{~g} / \mathrm{kg}$, found an increase in SGPT and SGOT levels when compared to K1. Twenty five percent ethanol was given on Group 3 (K3) at a dose of $2.5 \mathrm{~g} / \mathrm{kg}$ body weight, showed levels of SGPT and SGOT close to K1 even with an average lower.

This research has similarity with several previous studies. In a study using a dose of ethanol $40 \%$ as much as $3.76 \mathrm{~g} / \mathrm{kg}$ twice a day for 25 days showed differences in levels of ALT and AST were significantly when compared with the control group. ${ }^{13}$ Another study was carried out to assess the damage of the liver due to the effects of alcohol. Administration of $1 \mathrm{~mL} 20 \%$ alcohol for 21 days showed that varying levels of SGPT and SGOT are significant compared to the control group. ${ }^{14}$ Dose studies with others who also have shown differences in the levels of SGPT and SGOT very significant compared to the control group after the administration of $1.5 \mathrm{~mL}$ of $30 \%$ alcohol twice a day within 15 days..$^{15}$ Another study also mentions that the provision of $20 \%$ ethanol as much as $3.76 \mathrm{~g} / \mathrm{kg}$ for 18 days showed differences in levels of ALT and AST were significantly. ${ }^{9}$ 
Based on research result, it can be seen that by giving minimum of $20 \%$ ethanol in 1 $\mathrm{mL}$ for 18 days can lead to significant differences the levels of SGPT and SGOT compared to the control group. Minimum duration that can show differences in SGPT and SGOT levels was 15 days in previous studies. Provision of $30 \%$ ethanol in $1.5 \mathrm{~mL}$ with duration of 15 days has already been proved the increase of ALT levels up to 300U/L in test animals, which indicates the highest level compared to other studies that were executed in a longer duration of time. ${ }^{15}$

These studies also show that the greater the concentration, dose, and duration of ethanol are exposed, the greater damage occurs in the liver. In this study administration of $20 \%$ ethanol at a dose of $2 \mathrm{~g} / \mathrm{kg}$ showed an increase of SGPT and SGOT levels than the control group.

The increase in SGPT and SGOT levels in K2 rat group as compared to $\mathrm{K} 1$, illustrates the possibility of liver damage induced by ethanol exposure in the long term. The higher levels of serum ALT and AST increases the damage to the liver organ and leads acute inflamed liver, such as viral hepatitis, fatty liver and alcoholic liver disease. Exposure to ethanol continuously causes damage to liver cells. ${ }^{8}$ Essential organelles that are the target because ethanol is a mitochondrial damage. Mitochondrial dysfunction causes damage to the energy metabolism and the formation of intracellular oxidative stress. ${ }^{13}$ Intracellular oxidative stress starting from the entry of ethanol that causes hypoxia in the liver cells then initiate the enzyme xanthine dehydrogenation into xanthine oxidase. The formation of xanthine oxidase generates reactive oxygen species (ROS) such as superoxide anion and hydrogen peroxide. ROS compound is called as oxidants or free radicals, unstable molecules that are actively looking pair of electrons to the electron-deficient atom. Free radicals are very active to react with molecules in the surrounding areas. These free radicals may increase the damage to the liver by increasing the production of inflammatory cytokines such as IL1, IL-6, and TNF-alpha. ${ }^{17}$ In addition to stimulating the formation of ROS, ethanol is also optimally oxidized to acetic acid as the fatty acid precursors. Buildup of fatty acids in the cells of hepatocytes will cause damage to the liver. ${ }^{18}$ Broadly speaking, the damage caused by excessive alcohol consumption caused by the formation of ROS, accumulation of fat and the occurrence of inflammatory reactions. ${ }^{13}$ Condition that occurs in the liver is called alcoholic hepatitis. In line with the research that has been done with the existing theory, liver damage will result in increased serum levels of SGPT and SGOT.

In this study SGPT and SGOT levels of group $\mathrm{K} 3$ in rat is a group with $25 \%$ ethanol treated with the higher dose $(2,5 \mathrm{gm} / \mathrm{kg})$, showed an average lower than the control group.

In the chronic alcohol exposure to excessive and persistent initially leads to accumulation of fat in the cells of hepatocytes and causes an inflammatory reaction. Inflammatory reaction will continue to increase damage, if the longer exposure to alcohol or more increased dose of accumulation occurs. The continuous progression of the inflammatory reaction due to the increase of damage makes the condition of fibrosis or liver cell death. Fibrosis and mortality in liver cells will lead to a condition called cirrhosis of the liver. ${ }^{18}$

SGPT and SGOT levels in liver cirrhosis remains normal or increased only slightly, or even lower than the normal levels. ${ }^{19}$ This is because the cells of chronic liver damage and massive is no longer able to generate a liver enzyme that is SGPT and SGOT. Chronic liver damage and massive damage of liver can be seen by histological examination.

There are still many possibilities that affect the levels of SGPT and SGOT in rat. Factor that may affect the levels of SGOT is any damage to other organs because of the given treatment.

No significant difficulty was experienced during the study. However, there are still many shortcomings data and test results in order to do a comparison of variable more diverse such as the absence of data prior to treatment, increased doses are less significant, and small treatment group.

\section{CONCLUSION}

From these results it can be concluded that there are significant differences on levels of SGPT in each treatment group compared to the control group, but not at the levels of SGOT 


\section{SUGGESTION}

Tests should be performed before treatment to see the average normal levels of SGPT and SGOT in Wistar rats (Rattus norvegicus). Other tests need to be done, such as histological examination to determine the damage to other organs that may affect the levels of SGOT. Further research can be conducted with more significant differences in dose, more dose variation, and longer time.

\section{REFERENCES}

1. Guyton AC, Hall JE. Medical Physiology 11th Edition Jakarta: Book Medical Publishers EGC; 2007.

2. Sherlock S. Disease of The Liver and Billiary System (11th ed). USA: Wiley-Blackwell; 2002.

3. Joewana S. Mental and Behavioural Disorders due to Psychoactive Substance Use, Abuse Drug/Drug (2nd ed). Jakarta: Book Medical Publisher EGC; 2005.

4. Masters SB. Basic and Clinical Pharmacology: Alcohol. Jakarta: Salemba Medika; 2002.

5. World Health Organization. Global status report on noncommunicable diseases 2010. Geneva: World Health Organization; 2014.

6. National Institute of Alcohol Abuse and Alcoholism. Helping Patient Who Drink Too Much. Downloaded at <http://pubs.niaaa. nih. gov/publications/Practitioner/CliniciansGuide2005/clinicians_guide. htm>. 2005

7. World Health Organization, 2004. Global Status Report on Alcohol. downloaded at $<$ http://www.who.int/substance_abuse/ publications/global_status_report_2004_ overview.pdf. $>2004$.

8. Smeltzer SC, Bare BG. Textbook of Medical Surgical Nursing Brunner and Suddarth.Ed.8. Jakarta: EGC; 2002.

9. Shah P, Parmar M, Thakkar V, Gandhi T. Hepatoprotective Activity Of Hordeum Vulgare Linn, Seeds Adainst Ethanol-Induced Liver Damage In Rats. Pharmacologyonline. 2009;2:538-45.

10. Fleming KM, Aithal GP, Solaymani-Dodaran M, Card TR, West J. Incidence and Prevalence of Cirrhosis in The United Kingdom, 19922001: A General Population-based Study. J Hepatol 2007;49:732-8.

11. Thapa BR, WaliaA.Liver function test and their interpretation. Indian J Pedi- atri.74(4):663-70

12. Spooner L. Aspartate Aminotransferase. Israel: Proteopedia; 2014.

13. Modi H, Patel V, Patel K. Hepatoprotective Activity Of Aegle Marrmelos Against Ethanol Induced Hepatotoxicity In Rats.AJPCR.2012;5(4)164-7.

14. Arun $K$, Suguna $S$, Balasubramanian U, Yusoff M, Pragas G, Maniam, Serfoji P, Govindan N. Hepatoprotective Activity Of Cinnamon Zeylanicum Leaves Against Alcohol Induced Albino Rats. Journal of Enggineering Research and Applications. 2014;4(8):177-84.

15. Mallik D, Bhattacharjee C, Gouda S. Pharmacological Intervention of The Fruit of Plant Ananas comosus Acting As Hepatoprotective Activity In Animal Models. IJRPB. 2014;2(3):1167-72.

16. Choudary U, Augustine B, Lahkar M, Mathew A. Hepatoprotective Effect Of Azadiraohta Indica (Neem) In Alcoholic-Induced Liver Damage. World J Pharm Res.2014;3(4):1913-25.

17. Fuad BF. Science Textbook of Liver Diseases. Jakarta: Sagung Seto; 2012.

18. Tatiya A, Surana S, Sutar M, Gamit N. Hepatoprotective Effect of Poly Herbal Formulation Against Various Hepatotoxic Agents In Rats. Pharmacognosy Res. 2012;4(1):50-6.

19. Widjaja,S. Diagnosis of Liver Disorders Physiology.<http:// www.medistra.com. 2007.> 